\title{
THE EFFECTS OF A VARIETY OF HEMODYNAMIC CHANGES \\ ON THE RAPID AND SLOW COMPONENTS OF THE CIRCULATION IN THE HUMAN FOREARM ${ }^{1}$
}

\author{
BY EDWARD D. FREIS AND HAROLD W. SCHNAPER \\ (From the Cardiovascular Research Laboratory, Georgetown University School of Medicine, \\ and the Veterans Administration Hospital, Washington, D. C.)
}

(Submitted for publication July 23, 1957; accepted February 20, 1958)

When a tracer substance which does not diffuse through the capillary walls is introduced into the brachial artery and the effluent blood is sampled continuously thereafter, a time-concentration curve of the labeled substance may be plotted which describes the velocity-flow pattern of the blood in the forearm (1). It was found that the descending limb of the time-concentration curve usually was biphasic. Evidence was presented which indicated that these biphasic curves were not due to differences in path lengths or to velocity flow through different tissues such as skin and muscle. It was suggested that this biphasic pattern was due to two basically different rates of flow in the highly anastomotic small vessel circulation (1-3). Since pressures are very nearly equal at either end of an anastomotic intercapillary or intervenular channel, flow may be sluggish in that channel. Direct observation of the circulation in the hamster cheek pouch disclosed that varying rates and direction of flow occur in the anastomotic channels-at times rapid, at times slow, at times surging, stopping or reversing.

It seemed of interest to determine what effect changes in both the local and general circulation would have upon the characteristics of this biphasic velocity-flow pattern in the forearm.

\section{METHODS}

The dye T-1824 was used as the tracer substance. The source of subjects, experimental technique, methods of analysis and calculation of results were identical to those previously described (1). The ratio of blood flow in the rapid component $\left(f_{1}\right)$ to that in the slow $\left(f_{2}\right)$ was estimated from the mean circulation times of the total curve $(T)$, the rapid component $\left(t_{1}\right)$, and the slow component $\left(t_{2}\right)$ as described in a previous paper (1). The parameters $f_{1} / f_{2}$ and $t_{1} / t_{2}$ were used to estimate the ratio of the

1 Supported in part by United States Public Health Service Grants H-720 and H-1903 (National Heart Institute). blood volumes $\left(v_{1} / v_{2}\right)$ in the rapid and slow portions. The ratio of flows rather than absolute blood flows were estimated because the distribution of dye in the various branches of the brachial artery may not be uniform, and hence, the peripheral vasculature of the forearm cannot be regarded as a uniform mixing chamber (1).

Hyperemia restricted to the forearm under study was produced by the following techniques: 1) by the local intra-arterial injection of $5 \mathrm{mg}$. tolazoline (Priscoline(8)). After flushing of the skin had become plainly evident (usually after one to three minutes) the dye T-1824 was injected into the brachial artery; 2) by local exercise in which the subject squeezed a hand ergometer repeatedly at one-second intervals as forcibly as he was able until he could carry on no longer because of fatigue and aching of the forearm muscles. This varied from 65 to 124 squeezes in the 3 subjects. At this point the dye was injected through the previously placed intra-arterial needle without delay; 3) by reactive hyperemia in which the cuff of a blood pressure apparatus was wrapped on the upper arm and inflated to pressures $100 \mathrm{~mm}$. $\mathrm{Hg}$ above systolic for a period of 10 minutes. Dye was injected immediately following release of the cuff.

In all of the hyperemia experiments it was necessary to double the dose of T-1824 in the experimental as compared to the control period. The reason for this was that the greatly increased volume flow reduced the dye concentrations. In all of the other procedures the dosage of the dye was the same in both the experimental and control periods.

Local injection of epinephrine and norepinephrine was carried out as follows: Epinephrine was diluted to a concentration of $0.4 \mu \mathrm{g}$. per $\mathrm{ml}$. and levarterenol (norepinephrine) to $2.0 \mu \mathrm{g}$. per $\mathrm{ml}$. in isotonic saline. These dilute solutions were injected intra-arterially through a threeway stopcock at a rate of $2 \mathrm{ml}$. per minute. When pallor of the skin occurred (usually after one to two minutes) an assistant attached the syringe containing the dye to the free arm of the three-way stopcock and injected it without delay. Following this the stopcock was immediately turned and the infusion of the pressor amine continued at the same even rate until the end of the collection period. The pressor amine also was added to the dye in a concentration similar to that present in the infusion. The blood pressure was recorded in the opposite arm. In no instance was a significant change in systemic arterial pressure observed.

When epinephrine and norepinephrine were given sys- 
temically the infusion contained either $1 \mathrm{mg}$. of epinephrine or $2 \mathrm{mg}$. of norepinephrine per liter of isotonic saline. The infusion was connected via a three-way stopcock to a needle in a vein of the arm opposite to the forearm under study. A flask containing 1 liter of isotonic saline without added pressor amine was connected to the free limb of the three-way stopcock and infused slowly during the control period. Following the control experiment the stopcock was turned and the infusion of pressor amine was adjusted until a significant change in blood pressure and usually of the heart rate was obtained. The dye was then injected into the brachial artery of the forearm under study and the infusion rate of the pressor drug maintained at a level which produced a significant blood pressure change throughout the sample collection period. In the case of epinephrine the effective infusion rates averaged $15 \pm 5 \mu \mathrm{g}$. per minute; for norepinephrine they averaged $36 \pm 8 \mu \mathrm{g}$. per minute.

In the venous congestion experiments a narrow blood pressure cuff was wrapped proximally on the arm under study and covered with gauze bandage to prevent ballooning. The cuff was inflated to pressures of 40 to $60 \mathrm{~mm}$. $\mathrm{Hg}$ for a period of five minutes before as well as throughout the injection and collection periods.

\section{RESULTS}

Control determinations were carried out immediately prior to the experimental period in 25 of the 47 subjects. Controls, being technically laborious, were not obtained in the remaining cases. Therefore, in analyzing the data, some with controls, some without, the coefficients of variation were used to obtain a combined estimate of the standard deviation. This seemed valid since the ratio of the standard deviation to the mean was nearly constant for the various groups (Table I). Using this combined estimate the $t$ test for significance then was applied in the usual way. In the group of subjects given norepinephrine sufficient controls were carried out among these subjects to permit an intragroup comparison. The latter method of analysis was carried out in this case since the combined estimate provided suggestive but not conclusive indications of a significant difference.

\section{Hyperemia}

This was produced in several ways as described above: by local exercise (three cases), intra-arterial tolazoline (eight cases), and reactive hyperemia (four cases). Overall results indicated a highly significant shortening of $T$ and $t_{2}(p>$
$0.01)$ with an increase in the ratios $f_{1} / f_{2}(p>$ $0.01)$ and $v_{1} / v_{2}(p>0.05)$, indicating a marked relative shift of blood flow and volume to the rapid component (Tables I and II). These changes were most marked in the cases given intra-arterial tolazoline (Table I and Figure 1).

Control determinations were carried out in three cases with local exercise, in two of the subjects given intra-arterial tolazoline, and in one case subjected to reactive hyperemia. In each of these there were decreases in mean circulation times and increases in $f_{1} / f_{2}$ and $v_{1} / v_{2}$ as compared to the controls (Table I and Figure 1).

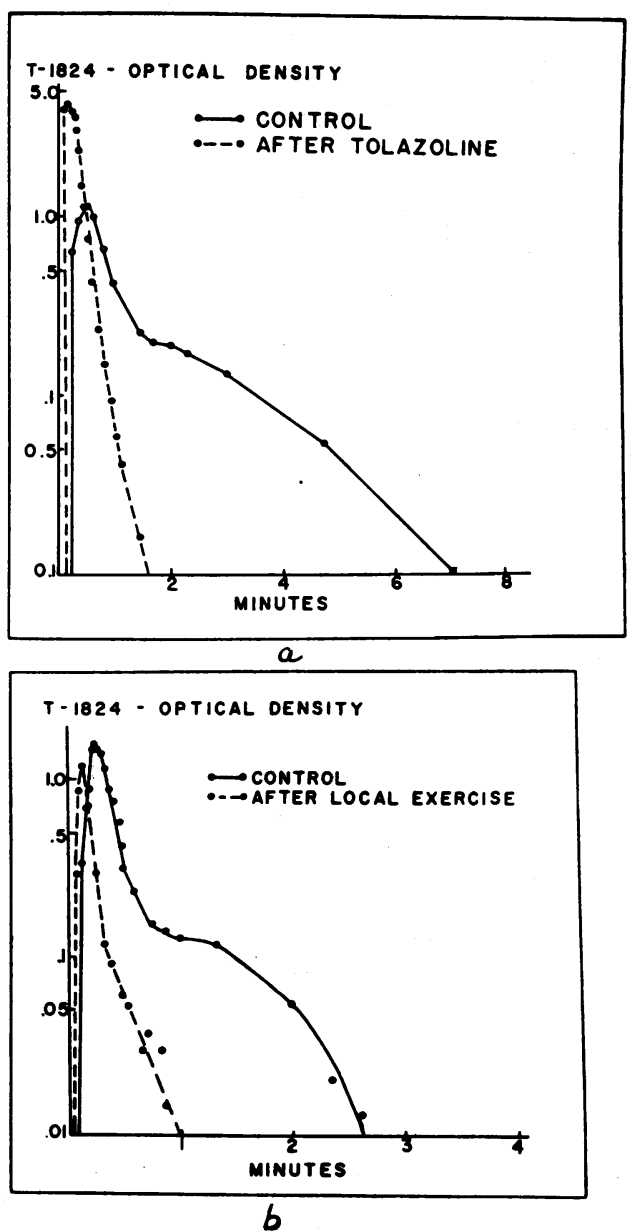

Fig. 1. Typical Effects of Hyperemia on the Biphasic Time-Concentration Curves in the Human ForeARM

Figure 1a (above) illustrates the effects of intraarterial tolazoline. Figure 1b (below) shows the effects of local exercise. 
TABLE I

Mean circulation times and ratios of blood flow and vascular volume in the rapid and slow components under various experimental conditions

\begin{tabular}{|c|c|c|c|c|c|c|c|c|c|c|c|c|}
\hline \multirow[b]{2}{*}{ Subject } & \multirow[b]{2}{*}{ Age } & \multirow[b]{2}{*}{ Diagnosis } & \multicolumn{5}{|c|}{ Control } & \multicolumn{5}{|c|}{ Experimental } \\
\hline & & & $T$ & $t_{1}$ & $t_{2}$ & $f_{1} / f_{2}$ & $\mathbf{v}_{\mathbf{1}} / \mathbf{v}_{\mathbf{2}}$ & $T$ & $t_{1}$ & $t_{2}$ & $f_{1} / f_{2}$ & $\mathbf{v}_{\mathbf{2}} / \mathbf{v}_{\mathbf{2}}$ \\
\hline
\end{tabular}

Local exercise

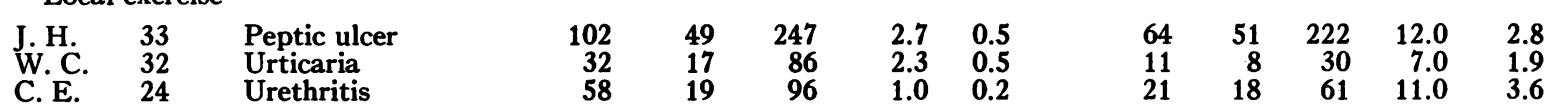

Intra-arterial tolazoline

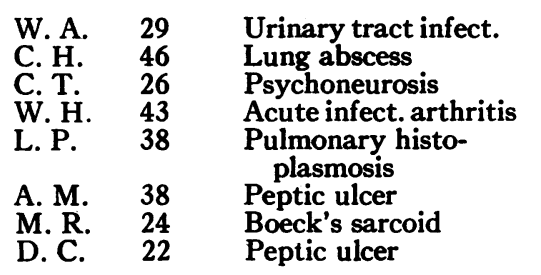

Reactive hyperemia

H. D. $35 \quad$ Multiple sclerosis

J. M. 32 Infectious arthritis

Pneumonia

\section{Mean}

S. D.

Venous congestion
B. B. 26
$\begin{array}{ll}\text { A. M. } & \mathbf{5 7} \\ \text { W. H. } & \mathbf{3 5}\end{array}$
Psychoneurosis
Gout
Normal
$\begin{array}{ll}\text { J. G. } & 28 \\ \text { R. H. } & 47\end{array}$
Rheum. spond.
Gastroenteritis
Mean
S. D.

Norepinephrine (intra-arterial)

\begin{tabular}{|c|c|c|}
\hline $\begin{array}{l}\text { J. C. } \\
\text { D. H. } \\
\text { R. N. } \\
\text { E. G. } \\
\text { L. G. } \\
\text { C. M. }\end{array}$ & $\begin{array}{l}35 \\
24 \\
46 \\
48 \\
37 \\
34\end{array}$ & $\begin{array}{l}\text { Cirrhosis } \\
\text { Rheum. arthritis } \\
\text { Diab. mellitus } \\
\text { No disease } \\
\text { Peptic ulcer } \\
\text { Convalescent }\end{array}$ \\
\hline $\begin{array}{l}\text { D. S. } \\
\text { G. S. } \\
\text { W. K. }\end{array}$ & $\begin{array}{l}33 \\
42 \\
35\end{array}$ & $\begin{array}{l}\text { Peptic ulcer } \\
\text { Penicillin reaction } \\
\text { Rheum. arthritis }\end{array}$ \\
\hline
\end{tabular}

\section{Mean}

S. D.

Epinephrine (intra-arterial)
P. N. $\quad 44$
$\begin{array}{ll}\text { C. M. } & 42 \\ \text { G. S. } & 35\end{array}$
M. M. 28
W. L. 23
Peptic ulcer
Psychoneurosis
Irritable colon
F. H. 41
Peptic ulcer
Convalescent
meningitis
E. D. $41 \quad$ Peptic ulcer

Mean

S. D.

$\begin{array}{lllll}92 & 33 & 179 & 1.5 & 0.3\end{array}$

$\begin{array}{lllll}82 & 15 & 97 & 0.2 & 0.1\end{array}$

$\begin{array}{llllll}49 & 24 & 79 & 1.2 & 0.3\end{array}$

$\begin{array}{lllll}38 & 30 & 113 & 8.6 & 2.2 \\ 89 & 31 & 123 & 0.6 & 0.2\end{array}$

$\begin{array}{lllll}89 & 31 & 123 & 0.6 & 0.2\end{array}$

$\begin{array}{lllll}83 & 43 & 135 & 1.3 & 0.4 \\ 71 & 21 & 112 & 0.9 & 0.2 \\ 62 & 19 & 127 & 1.5 & 0.2\end{array}$

$\begin{array}{rrrrr}92 & 16 & 168 & 1.0 & 0.1 \\ 44 & 14 & 86 & 1.4 & 0.2 \\ 40 & 15 & 75 & 1.4 & 0.3\end{array}$

$\begin{array}{lll}75 & 20 & 125\end{array}$

$0.9 \quad 0.1$

$\begin{array}{rrrrr}16 & 16 & 46 & 150.4 & 51.1 \\ 24 & 24 & 75 & 127.1 & 39.9 \\ 18 & & & & \\ 17 & 15 & 46 & 16.2 & 5.3 \\ 22 & & & & \\ 16 & 14 & 60 & 33.3 & 7.9 \\ 19 & 15 & 42 & 5.2 & 1.9 \\ 22 & 12 & 65 & 4.3 & 0.8\end{array}$

$\begin{array}{rrrrr}23 & & & & \\ 20 & 16 & 53 & 8.9 & 2.7 \\ 27 & 13 & 46 & 1.4 & 0.4 \\ 17 & 9 & 49 & 3.9 & 0.7 \\ 25 & 18 & 68 & 33.8 & 10.7 \\ \pm 14 & \pm 12 & \pm 60 & \pm 58.4 & \pm 19.4\end{array}$

$\begin{array}{rrrrr}149 & 55 & 223 & 0.8 & 0.2 \\ 307 & 127 & 652 & 2.1 & 0.4 \\ 210 & 54 & 251 & 0.3 & 0.1 \\ 209 & 125 & 406 & 2.3 & 0.1 \\ 215 & 48 & 320 & 0.6 & 0.1 \\ & & & & \\ 218 & 82 & 370 & 1.2 & 0.2 \\ \pm 57 & \pm 40 & \pm 172 & \pm 0.9 & \pm 0.2\end{array}$

$\begin{array}{rrrrr}93 & 46 & 129 & 0.6 & 0.2 \\ 76 & 21 & 132 & 1.0 & 0.2 \\ 130 & 41 & 203 & 0.8 & 0.2 \\ 61 & 26 & 122 & 1.7 & 0.4 \\ 120 & 36 & 231 & 1.3 & 0.2 \\ 87 & 48 & 190 & 2.6 & 0.6 \\ 57 & 22 & 118 & 1.7 & 0.3 \\ 100 & 40 & 148 & 0.8 & 0.2 \\ 127 & 24 & 73 & 1.1 & 0.2 \\ 95 & 34 & 150 & 1.3 & 0.3 \\ \pm 26 & \pm 10 & \pm 45 & \pm 0.6 & \pm 0.14\end{array}$

$\begin{array}{rrrrr}63 & 18 & 139 & 1.7 & 0.2 \\ 41 & 19 & 97 & 2.6 & 0.5 \\ 55 & 21 & 106 & 1.5 & 0.3 \\ 54 & & & & \\ 34 & 13 & 78 & 2.1 & 0.3 \\ & & & & \\ 61 & 38 & 104 & 1.9 & 0.7 \\ 60 & 16 & 126 & 1.5 & 0.2 \\ & & 108 & 1.8 & 0.4 \\ 52 & 21 & 108 & \pm 0.5 & \pm 0.4\end{array}$


TABLE I-Continued

\begin{tabular}{|c|c|c|c|c|c|c|c|c|c|c|c|c|}
\hline \multirow[b]{2}{*}{ Subject } & \multirow[b]{2}{*}{ Age } & \multirow[b]{2}{*}{ Diagnosis } & \multicolumn{5}{|c|}{ Control } & \multicolumn{5}{|c|}{ Experimental } \\
\hline & & & $T$ & $t_{1}$ & $t_{2}$ & $\mathbf{f}_{1} / \mathbf{f}_{\mathbf{2}}$ & $\mathrm{v}_{1} / \mathrm{v}_{\mathbf{2}}$ & $T$ & $t_{1}$ & $t_{2}$ & $f_{1} / f_{2}$ & $\mathrm{v}_{1} / \mathbf{v}_{\mathbf{2}}$ \\
\hline \multicolumn{3}{|c|}{$\begin{array}{l}\text { yrs. } \\
\text { Epinephrine (systemic) }\end{array}$} & \multicolumn{5}{|c|}{ seconds } & \multicolumn{5}{|c|}{ seconds } \\
\hline S. W. & 21 & $\begin{array}{c}\text { Convalescent } \\
\text { pneumonia }\end{array}$ & 47 & 18 & 117 & 2.4 & 0.4 & 34 & 12 & 81 & 2.2 & 0.3 \\
\hline $\begin{array}{l}\text { M. K. } \\
\text { D. C. } \\
\text { H.S. }\end{array}$ & $\begin{array}{l}28 \\
39 \\
31\end{array}$ & $\begin{array}{l}\text { Psychoneurosis } \\
\text { Peptic ulcer } \\
\text { Pyeloneph. right }\end{array}$ & $\begin{array}{r}72 \\
57 \\
109\end{array}$ & $\begin{array}{l}27 \\
16 \\
46\end{array}$ & $\begin{array}{r}180 \\
80 \\
159\end{array}$ & $\begin{array}{l}0.7 \\
0.6 \\
0.8\end{array}$ & $\begin{array}{l}0.2 \\
0.1 \\
0.2\end{array}$ & $\begin{array}{r}103 \\
47 \\
135\end{array}$ & $\begin{array}{l}40 \\
15 \\
56\end{array}$ & $\begin{array}{r}144 \\
80 \\
250\end{array}$ & $\begin{array}{l}0.7 \\
1.1 \\
1.6\end{array}$ & $\begin{array}{l}0.2 \\
0.2 \\
0.3\end{array}$ \\
\hline \multicolumn{3}{|c|}{$\begin{array}{l}\text { Mean } \\
\text { S. D. }\end{array}$} & & & & & & $\begin{array}{r}80 \\
\pm 43\end{array}$ & $\begin{array}{r}31 \\
\pm 21\end{array}$ & $\begin{array}{r}139 \\
\pm 80\end{array}$ & $\begin{array}{r}1.4 \\
\pm 0.6\end{array}$ & $\begin{array}{r}0.25 \\
\pm 0.06\end{array}$ \\
\hline \multicolumn{13}{|c|}{ Norepinephrine (systemic) } \\
\hline $\begin{array}{l}\text { W. J. } \\
\text { O. Y. }\end{array}$ & $\begin{array}{l}38 \\
33\end{array}$ & $\begin{array}{l}\text { No disease } \\
\text { Convalescent } \\
\text { spontaneous } \\
\text { pneumothorax }\end{array}$ & $\begin{array}{l}22 \\
75\end{array}$ & $\begin{array}{r}19 \\
39\end{array}$ & $\begin{array}{r}67 \\
164\end{array}$ & $\begin{array}{l}3.6 \\
2.4\end{array}$ & $\begin{array}{l}3.2 \\
0.6\end{array}$ & $\begin{array}{l}25 \\
41\end{array}$ & $\begin{array}{l}16 \\
36\end{array}$ & $\begin{array}{r}86 \\
120\end{array}$ & $\begin{array}{r}7.0 \\
14.6\end{array}$ & $\begin{array}{l}1.3 \\
4.3\end{array}$ \\
\hline J.P. & 30 & $\begin{array}{c}\text { Convalescent } \\
\text { pneumonia }\end{array}$ & 44 & 24 & 77 & 1.7 & 0.5 & 33 & 29 & 87 & 11.8 & 3.9 \\
\hline $\begin{array}{l}\text { C. P. } \\
\text { G. T. } \\
\text { G. W. }\end{array}$ & $\begin{array}{l}26 \\
34\end{array}$ & $\begin{array}{l}\text { Peptic ulcer } \\
\text { Boeck's sarcoid } \\
\text { Traumatic wrist } \\
\text { dron }\end{array}$ & $\begin{array}{r}73 \\
137\end{array}$ & $\begin{array}{l}28 \\
25\end{array}$ & $\begin{array}{l}123 \\
174\end{array}$ & $\begin{array}{l}1.1 \\
0.3\end{array}$ & $\begin{array}{l}0.3 \\
0.06\end{array}$ & $\begin{array}{r}75 \\
33 \\
128\end{array}$ & $\begin{array}{l}30 \\
26 \\
29\end{array}$ & $\begin{array}{l}162 \\
103 \\
188\end{array}$ & $\begin{array}{l}2.0 \\
9.4 \\
0.6\end{array}$ & $\begin{array}{l}0.4 \\
2.3 \\
0.09\end{array}$ \\
\hline G. R. & 26 & No disease & 97 & 18 & 132 & 0.4 & 0.1 & 70 & 20 & 128 & 1.2 & 0.2 \\
\hline \multicolumn{3}{|c|}{$\begin{array}{l}\text { Mean } \\
\text { S. D. }\end{array}$} & $\begin{array}{r}75 \\
\pm 38\end{array}$ & $\begin{array}{r}26 \\
\pm 8\end{array}$ & $\begin{array}{r}123 \\
\pm 44\end{array}$ & $\begin{array}{r}1.6 \\
\pm 1.3\end{array}$ & $\begin{array}{r}0.8 \\
\pm 1.2\end{array}$ & $\begin{array}{r}58 \\
\pm 24\end{array}$ & $\begin{array}{r}27 \\
\pm 7\end{array}$ & $\begin{array}{r}125 \\
\pm 12\end{array}$ & $\begin{array}{r}6.7 \\
\pm 5.5\end{array}$ & $\begin{array}{r}1.8 \\
\pm 1.8\end{array}$ \\
\hline \multicolumn{3}{|c|}{$\begin{array}{l}\text { Mean (all controls) } \\
\text { S. E. (all controls) }\end{array}$} & $\begin{array}{r}65.7 \\
\pm 22.7\end{array}$ & $\begin{array}{l}25 \\
\pm 10.8\end{array}$ & $\begin{array}{r}125.2 \\
\pm 43.8\end{array}$ & $\begin{array}{r}1.6 \\
\pm 1.8\end{array}$ & $\begin{array}{r}0.5 \\
\pm 0.7\end{array}$ & & & & & \\
\hline
\end{tabular}

\section{Venous congestion}

In the five subjects studied there were marked prolongations of mean circulation times (Tables I and II, Figure 2). These were significant for $T, t_{1}$ and $t_{2}$ ( $p>0.05,0.05$ and 0.01 , respectively). Because of the nearly proportionate increase in all of these parameters the changes in $f_{1} / f_{2}$ and $\mathrm{v}_{1} / \mathrm{v}_{2}$ were not significant. It should be noted that the number of cases studied was not sufficient to detect small changes in these ratios. It would appear, however, that the predominant effects of congestion were to greatly retard blood flow and velocity in both components without much change in the relative flows and volumes.

\section{Local epinephrine and norepinephrine}

The changes observed after the intra-arterial infusion of epinephrine and norepinephrine were not significant. Following norepinephrine the average values in nine cases disclosed slight and insignificant increases in mean circulation times and reductions in $f_{1} / f_{2}$ and $v_{1} / v_{2}$ (Tables I and II). In the three cases in which control determinations immediately preceded the experimental period the only change consistent in all three was a slight to moderate increase in $\mathrm{T}(7,15$ and 109 per cent, respectively).

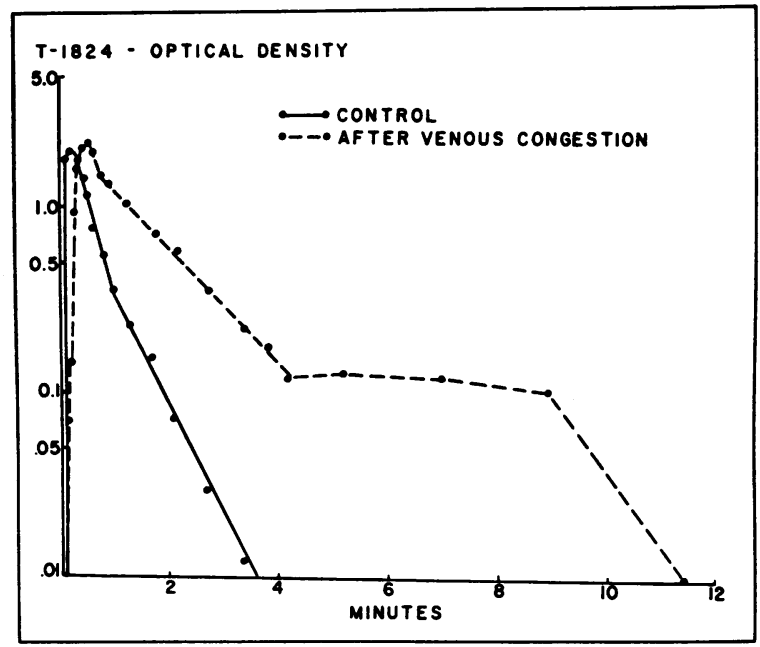

Fig. 2. Effects of Venous Congestion See text for details. 
TABLE II

Means, standard deviation of means, and statistical analysis of the

\begin{tabular}{|c|c|c|c|c|c|c|c|c|c|c|c|}
\hline \multirow[b]{3}{*}{ Procedure } & \multirow[b]{3}{*}{$\begin{array}{l}\text { No. of } \\
\text { cases }\end{array}$} & \multicolumn{5}{|c|}{$\mathbf{T}$} & \multicolumn{5}{|c|}{$\mathbf{t}_{\mathbf{1}}$} \\
\hline & & \multirow[b]{2}{*}{ Mean } & \multirow[b]{2}{*}{ S.D. } & \multicolumn{2}{|c|}{$\begin{array}{c}\text { Difference } \\
\text { between means* }\end{array}$} & \multirow[b]{2}{*}{$\mathbf{t}$} & \multirow[b]{2}{*}{ Mean } & \multirow[b]{2}{*}{ S.D. } & \multicolumn{2}{|c|}{$\begin{array}{c}\text { Difference } \\
\text { between means }\end{array}$} & \multirow[b]{2}{*}{$\mathbf{t}$} \\
\hline & & & & $\begin{array}{l}\text { Differ- } \\
\text { ence }\end{array}$ & $\begin{array}{l}\text { S.D. } \\
\text { of diff. }\end{array}$ & & & & $\begin{array}{l}\text { Differ- } \\
\text { ence }\end{array}$ & $\begin{array}{l}\text { S.D. } \\
\text { of diff. }\end{array}$ & \\
\hline Control & 25 & 66 & 23 & & & & 25 & 11 & & & \\
\hline Hyperemia & 15 & 25 & 14 & 41 & 6 & 6.5 & 18 & 12 & 7 & 3 & 2.2 \\
\hline Congestion & 5 & 218 & 57 & 152 & 37 & 4.1 & 82 & $\mathbf{4 0}$ & 57 & 19 & $\mathbf{3 . 0}$ \\
\hline Epinephrine, local & 7 & 52 & 10 & 14 & 11 & 1.3 & 21 & 9 & 4 & 5 & 0.8 \\
\hline Norepinephrine, local & 9 & 95 & 26 & 29 & 17 & 1.7 & 34 & 10 & 9 & 6 & 1.5 \\
\hline Epinephrine, systemic & 4 & 80 & 43 & 14 & 12 & 1.2 & 31 & 21 & 6 & 8 & 0.7 \\
\hline Norepinephrine, systemic & 7 & 58 & 14 & 8 & 10 & 0.8 & 27 & 7 & 2 & 5 & 0.4 \\
\hline
\end{tabular}

* Coefficients of variation used to obtain a combined estimate of the standard deviation. See text.

In the seven cases receiving intra-arterial epinephrine no significant changes were observed in the average values of $T, t_{1}, t_{2}, f_{1} / f_{2}$ and $v_{1} / v_{2}$ as compared to the combined series of 25 controls. In four of these subjects control determinations preceded the experimental period. Results in these cases failed to reveal consistent changes in the mean circulation times. In three of the four cases moderate increases in $f_{1} / f_{2}$ and $v_{1} / v_{2}$ occurred. This must be regarded as being of questionable significance since the average values for the entire group of seven failed to confirm such a trend.

The changes after norepinephrine and epinephrine locally, therefore, were not striking. After norepinephrine there seemed to be a moderate delay in mean circulation time but this was not sta-

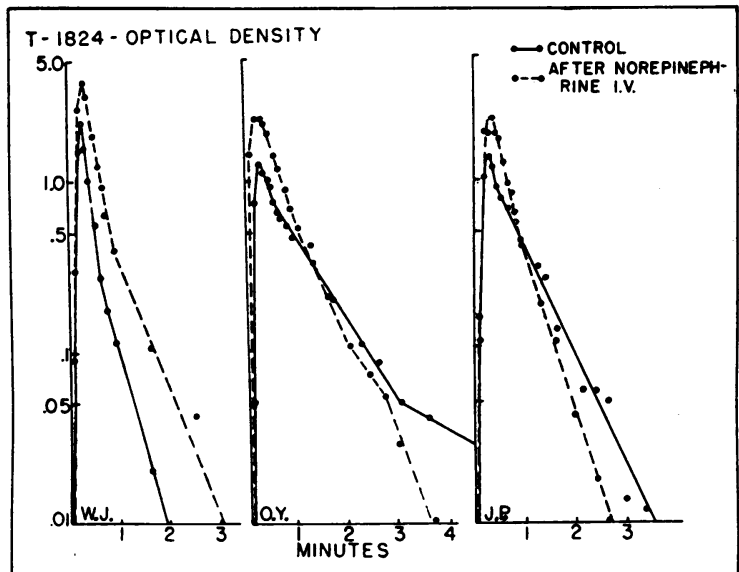

Fig. 3. Effects of Systemically Administered NorEPINEPHRINE IN ThreE SUbJeCtS

Note increased dye concentrations and broadening of the curve around the peak. tistically significant. After epinephrine no consistent changes were observed.

\section{Systemic norepinephrine and epinephrine}

Epinephrine was infused at a rate of 10 to $22 \mu \mathrm{g}$. per minute until there was a significant elevation of systolic pressure. This was always accompanied by a detectable fall in diastolic blood pressure. The mean elevation of systolic pressure was $34 \pm$ $8 \mathrm{~mm} . \mathrm{Hg}$, and the fall of diastolic pressure averaged $11 \pm 7 \mathrm{~mm} . \mathrm{Hg}$. The average increase in mean [ (systolic + diastolic)/2] pressure was only $11 \pm 5 \mathrm{~mm}$. Hg. The changes in mean circulation times, relative flows, and relative volumes in the two compartments failed to indicate any consistent pattern (Tables I and II).

Norepinephrine was infused at a rate to produce not only significant systolic but also diastolic hypertension and bradycardia. The average elevation of systolic pressure was $52 \pm 18 \mathrm{~mm}$. Hg and of diastolic pressure $30 \pm 5 \mathrm{~mm}$. $\mathrm{Hg}$, the increase in "mean" arterial pressure averaging $42 \pm$ $11 \mathrm{~mm} . \mathrm{Hg}$. Thus, the elevation of "mean" arterial pressure was approximately four times as great after norepinephrine as after epinephrine. The mean decrease in heart rate was $17 \pm 7$ beats per minute.

In contrast to the insignificant effects of epinephrine there was a significant decrease in $\mathrm{T}$ and increase in $f_{1} / f_{2}$ when the six cases with controls were compared on an intragroup basis (Table III). The ratio $f_{1} / f_{2}$ increased in all of the cases who had their own controls (Table I), the mean increase being 375 per cent over the control and the range 94 to 755 per cent. Although $t_{1}$ and $t_{2}$ 
TABLE II-Continued

differences between means under the various experimental conditions

\begin{tabular}{|c|c|c|c|c|c|c|c|c|c|c|c|c|c|c|}
\hline \multirow[b]{3}{*}{ Mean } & \multirow[b]{3}{*}{ S.D. } & \multicolumn{3}{|l|}{$t_{2}$} & \multicolumn{5}{|c|}{$f_{1} / f_{2}$} & \multicolumn{5}{|c|}{$v_{1} / v_{2}$} \\
\hline & & \multicolumn{2}{|c|}{$\begin{array}{c}\text { Difference } \\
\text { between means }\end{array}$} & \multirow[b]{2}{*}{$\mathbf{t}$} & \multirow[b]{2}{*}{ Mean } & \multirow[b]{2}{*}{ S.D. } & \multicolumn{2}{|c|}{$\begin{array}{c}\text { Difference } \\
\text { between means }\end{array}$} & \multirow[b]{2}{*}{$\mathbf{t}$} & \multirow[b]{2}{*}{ Mean } & \multirow[b]{2}{*}{ S.D. } & \multicolumn{2}{|c|}{$\begin{array}{c}\text { Difference } \\
\text { between means }\end{array}$} & \multirow[b]{2}{*}{$t$} \\
\hline & & $\begin{array}{l}\text { Differ- } \\
\text { ence }\end{array}$ & $\begin{array}{l}\text { S.D. } \\
\text { of diff. }\end{array}$ & & & & $\begin{array}{l}\text { Differ- } \\
\text { ence }\end{array}$ & $\begin{array}{l}\text { S.D. } \\
\text { of diff. }\end{array}$ & & & & $\begin{array}{l}\text { Differ- } \\
\text { ence }\end{array}$ & $\begin{array}{l}\text { S.D. } \\
\text { of diff. }\end{array}$ & \\
\hline 125 & 44 & & & & 1.6 & 1.7 & & & & 0.5 & 0.7 & & & \\
\hline 68 & 60 & 57 & 15 & 3.7 & 34 & 58 & 32 & 9 & 3.6 & 10.7 & 19.5 & 10 & 4 & 2.8 \\
\hline 370 & 172 & 245 & 8 & 31.0 & 1.2 & 0.9 & 0.4 & 0.6 & 0.7 & 0.2 & 0.2 & 0.3 & 0.16 & 1.8 \\
\hline 108 & 22 & 17 & 22 & 0.8 & 1.8 & 0.5 & 0.2 & 0.75 & 0.2 & 0.4 & 0.4 & 1.0 & 0.21 & 0.4 \\
\hline 150 & 45 & 25 & 25 & 1.0 & 1.3 & 0.6 & 0.3 & 0.4 & 0.8 & 0.3 & 0.14 & 0.2 & 0.17 & 1.1 \\
\hline 139 & 80 & 14 & 28 & 0.5 & 1.4 & 0.6 & 0.2 & 0.7 & 0.3 & 0.25 & 0.06 & 0.25 & 0.2 & 1.3 \\
\hline 125 & 12 & 0.2 & 25 & 0.004 & 6.7 & 5.5 & 5 & 2.4 & 2.2 & 1.8 & 1.8 & 1.3 & 0.8 & 1.6 \\
\hline
\end{tabular}

were not significantly changed from the controls they both increased in relation to the decrease in $T$. Inspection of the curves disclosed a uniform change characterized by a broadening of the curve with increased dye concentrations around the peak. The junction or transition zone between $t_{1}$ and $t_{2}$ was shifted to the right (Figure 3 ). Thus, norepinephrine given systemically in dosages sufficient to produce a significant elevation of "mean" arterial pressure, including diastolic pressure, seemed to produce a change in the distribution of blood flow so that a larger proportion was carried in the rapid component. This change apparently did not occur when norepinephrine was given locally nor when epinephrine was given locally or systemically in dosages to produce a systolic but not diastolic hypertension.

\section{DISCUSSION}

These studies demonstrate that the biphasic pattern of blood flow in the forearm is subject to dynamic changes. When total blood flow was augmented by any one of several means (local exercise, intra-arterial tolazoline, reactive hyperemia) flow in the rapid component increased relative to that in the slow component. The increase in flow of the rapid component was accompanied by an increase in the relative vascular volume of the rapid component. These data represent an extension of the previous observations on a group of subjects studied under resting conditions. In that series, $f_{1} / f_{2}$ and $v_{1} / v_{2}$ were found to be inversely related to $T(1)$.

Whereas the ratios $f_{1} / f_{2}$ and $v_{1} / v_{2}$ could be increased by various maneuvers, no means was found to significantly reduce them. Even venous con- gestion, which resulted in marked prolongation of the mean circulation times, probably reflecting a reduction in total blood flow (4), failed to produce a significant decrease in relative flow in the rapid as compared to the slow component. The local (intra-arterial) infusion of epinephrine and norepinephrine also failed to change the relationship between flows or volumes in the rapid as compared to the slow components.

It must be admitted, however, that the number of observations was not sufficient to rule out the possibility of minor changes in the measured parameters. In addition, the method of statistical analysis was more apt to underestimate than overestimate significant changes. Nevertheless, there were three cases with paired controls given norepinephrine intra-arterially and four given epinephrine. Inspection of these data fails to suggest the obvious and striking changes seen in other groups (Table I).

Epinephrine continuously infused intra-arterially produces no change in forearm blood flow while sustained intravenous infusion is followed by a slight vasodilation (5). Because of these opposing

TABLE III

Statistical analysis of data on six subjects given norepinephrine systemically, compared with their own controls

\begin{tabular}{ccl}
\hline \hline Parameter & $\begin{array}{c}\text { Mean difference between } \\
\text { means } \pm \text { standard error }\end{array}$ & $\mathrm{t}$ \\
\hline $\mathrm{T}$ & $19.7 \pm 6.2$ & $3.2^{*}$ \\
$\mathrm{t}_{1}$ & $0.5 \pm 1.45$ & 0.3 \\
$\mathrm{t}_{2}$ & $4.5 \pm 9.7$ & 0.5 \\
$\mathrm{f}_{1} / \mathrm{f}_{2}$ & $5.9 \pm 2.0$ & $2.9^{*}$ \\
$\mathrm{v}_{1} / \mathrm{v}_{2}$ & $1.2 \pm 0.9$ & 1.3 \\
\hline
\end{tabular}

* Significant at the 5 per cent level. 
actions, the total forearm flow representing both skin and muscle may not be significantly changed. Norepinephrine, on the other hand, is said to produce slight decreases in forearm or calf blood flow (6) which were somewhat more prominent after intra-arterial infusion (7). This constrictor effect may have accounted for the slight increase in $\mathrm{T}$ following intra-arterial norepinephrine. However, the failure to reduce the flow and volume ratios in the rapid as compared to the slow component by any of the various experimental maneuvers, including intra-arterial norepinephrine and venous congestion, suggests that in the normal resting state the ratios $f_{1} / f_{2}$ and $v_{1} / v_{2}$ approach their minimal values; and whereas these ratios can be made to increase considerably under various stresses, apparently they cannot easily be reduced.

A surprising observation was that flow in the rapid component increased relative to that in the slow component following systemic norepinephrine infusion. The increase in dye concentration following systemic norepinephrine indicates a reduction in total forearm blood flow or vascular volume, or both. The broadening out of the early portion of the curves also suggests this. However, the earlier "disappearance" time observed in five out of six cases suggests that the predominant effect was on vascular volume rather than on blood flow since a decrease in flow without a volume change would tend to prolong rather than shorten the disappearance time. Obviously, the elevated arterial pressure would also tend to counteract a possible decrease in blood flow. Plethysmographic measurements during norepinephrine infusions indicate only slight decreases in forearm blood flow (6). Thus, the characteristic change in the dye concentration curve following systemic norepinephrine seemed to be due to the combined effects of increased pressure and increased local vasoconstriction.

These observations are in keeping with the previous studies, indicating a decrease in peripheral vascular volume after norepinephrine (8). [The previous studies showed that epinephrine also had this activity in the dog, but it should be recalled that unlike man the hemodynamic effects of epinephrine in the dog resembled those of norepinephrine (9).] It was indicated that either sympathetic activity or norepinephrine reduces the volume of the small vessels, including postarterio- lar vessels, with a resulting increase in venous return.

It is suggested that the present data may throw further light on this phenonmenon. A decrease in $T$ and increase in the ratio $f_{1} / f_{2}$ could not occur as a result of arteriolar constriction alone, but must include postarteriolar narrowing as well. The failure of $v_{1} / v_{2}$ to change significantly indicates that both the rapid and slow components shared in the vasoconstriction. The net effect of such a decrease in peripheral vascular capacity, aided and abetted by an increase in arterial pressure, would be to increase the velocity of flow through the generally constricted peripheral vascular bed. The result would be more fast-moving and less slow-moving blood flow; that is, an increase in the ratio $f_{1} / f_{2}$.

\section{SUMMARY AND CONCLUSIONS}

Various experimental procedures were utilized to study their effects on the relationship between the rapid and slow components of blood flow in the human forearm (1). Local hyperemia produced by intra-arterial injection of tolazoline, reactive hyperemia, or local exercise increased the flow and volume in the rapid component relative to that in the slow component. Venous congestion resulted in marked but nearly proportionate prolongations of mean circulation times. The relative flows and volumes of the two components were not significantly changed. Local (intraarterial) infusion of either epinephrine or norepinephrine and systemic administration of epinephrine produced no obvious changes in these parameters although the number of cases, especially those with paired controls, was insufficient to rule out small changes. Systemic infusion of norepinephrine produced characteristic changes in the time-concentration curve of the dye, indicating a relative increase in blood flow of the rapid component. It is suggested that the latter was due to the hypertension plus vasoconstriction in the forearm occurring in response to significant elevation of mean pressure.

These observations demonstrate that the biphasic system of forearm blood flow and volume is dynamic, the relative proportion of the rapid and slow components changing under appropriate stimuli. The data also suggest that under normal 
resting conditions the ratios $f_{1} / f_{2}$ and $v_{1} / v_{2}$ are near the lower levels of their possible range.

\section{ACKNOWLEDGMENTS}

The authors are indebted to Drs. W. J. Youden and W. S. Connor, Jr., of the National Bureau of Standards, for advice and counsel in carrying out the statistical analysis of the data.

\section{REFERENCES}

1. Freis, E. D., Schnaper, H. W., and Lilienfield, L. S. Rapid and slow components of the circulation in the human forearm. J. clin. Invest. 1957, 36, 245.

2. Nicoll, P. A., and Webb, R. L. Vascular patterns and active vasomotion as determiners of flow through minute vessels. Angiology 1955, 6, 291.

3. Zweifach, B. W., and Metz, D. B. Selective distribution of blood through the terminal vascular bed of mesenteric structures and skeletal muscle. Angiology 1955, 6, 282.
4. Halperin, M. H., Freidland, C. K., and Wilkins, R. W. The effect of local compression upon blood flow in the extremities of man. Amer. Heart J. 1948, 35, 221.

5. Duff, R. S., and Swan, H. J. C. Further observations on the effect of adrenaline on the blood flow through human skeletal muscle. J. Physiol. 1951, 114, 41.

6. Duncanson, D., Stewart, T., and Edholm, O. G. The effect of 1-arteranol on the peripheral circulation in man. Fed. Proc. 1949, 8, 37.

7. Barcroft, $H$., and Konzett, $H$. Die Wirkung von Noradrenalin, N-Isopropylnoradrenalin (Aleudrin) und Adrenalin auf Blutdruck, Herzschlagzahl und Muskeldurchblutung am Menschen. Helv. physiol. pharmacol. Acta 1949, 7, C4.

8. Freis, E. D., and Rose, J. C. The sympathetic nervous system, the vascular volume and the venous return in relation to cardiovascular integration. Amer. J. Med. 1957, 22, 175.

9. Rose, J. C., Freis, E. D., Hufnagel, C. A., and Massullo, E. A. Effects of epinephrine and nor-epinephrine in dogs studied with a mechanical left ventricle. Amer. J. Physiol. 1955, 182, 197. 